\title{
The Idea of Europe at the Origins of the European People's Party. The Making of the European Manifesto and of the EPP's Political Programme
}

\author{
Jacopo CELLINI
}

\section{The history of an idea. European Christian Democracy and the idea of Europe after the Second World War}

After the Second World War, Christian Democratic parties (hereinafter, CD parties) of Western Europe had no institutionalized form of party cooperation. ${ }^{1}$ The frail transnational organisation Secrétariat International des Partis Démocrates d'Inspiration Chrétienne (SIPDIC), created in the 1920s, had been dismantled in the early 1930s, when most of its members were forbidden from doing political activity by authoritarian regimes in their home countries. Contacts between Christian Democratic representatives were mostly maintained on a personal and informal level, often by personalities who were forced to live in exile. ${ }^{2}$

After the war, when political freedom was restored in Western Europe, a new organisation had to be built from scratch. Thanks to the initiative of the Swiss Katholisch-Konservative Partei der Schweiz, the first official meeting between CD parties took place in Lucerne in 1947. Here two main lines confronted each other: the Swiss party, the Italian Democrazia Cristiana (DC) and the Austrian Österreichische Volkspartei (ÖVP) pushed for the creation of a strong International, ideologically consistent and institutionally formalized, while the French Mouvement Républicain Populaire (MRP) and the Belgian Christelijke Volkspartij-Parti Social Chrétien (CVP-PSC) preferred a looser network, impervious to accusations of confessionalism. The second line prevailed, leading to the creation of the Nouvelles Équipes Internationales (NEI), which consisted of individuals or groups (and also political parties) that shared some general principles like a personalist and communitarian view of society, and the pursuit of peace and international cooperation, especially in Europe.

1. Research for this article was funded by the Postgraduate Research Grant programme of the European People's Party (July 2017).

2. The history of Christian Democracy's transnational cooperation has already been addressed by historian Wolfram Kaiser in many publications, especially in his comprehensive W. KAISER, Christian Democracy and the Origins of the European Union, Cambridge University Press, Cambridge, 2007 (pp.42-162 for the interwar period). Jean-Dominique Durand argued that the exile experience was a founding moment of Christian Democratic internationalism throughout the twentieth century: see J.D. DURAND, Exile as a Matrix of Christian Democrat Internationalism, in: Idem. (ed.), Christian Democrat Internationalism. Its action in Europe and worldwide from post-World War II until the '90s, vol.I: The Origins, Peter Lang, Brussels, 2013, pp.145-157. 
The Germans were not invited to Lucerne, but they were involved in the informal gatherings of the so-called Geneva Circle (since 1947), where German and French Christian Democrats had the opportunity to get to know each other and discuss the terms of further collaboration in Europe. It is well known that the early stages of European integration were in large part an answer to the problem concerning the future of Germany (especially Franco-German reconciliation), but scientific literature has for a long time underestimated the importance of the transnational dimension, and the role of informal policy networks in this process, in favour of an approach strongly focused on the role of States and institutional actors. The study of transnational policy networks, on the contrary, provides useful insights on how pro-European ideas were able to circulate among European administrative and political élites, thus influencing the integration process, which took place from the 1950s onwards. ${ }^{3}$

In our case, NEI and Geneva circle were important forums, which contributed to shape the path to European integration. NEI were not created with the immediate goal of a united Europe, notwithstanding the retrospective characterization given by sympathetic accounts: the same participation to The Hague Congress in May 1948, which is usually considered the first federal moment in European history, was neither well prepared nor especially effective. ${ }^{4}$ At the same time, the very existence of these networks allowed for the confrontation between different concepts on the organisation of representative institutions at regional, national and European level, and on the principles that should orient them. In their meetings and congresses, Christian Democrats were obviously bound to deal with an overarching theme, that is: which idea of Europe was supposed to animate their political culture, and how should they work to implement it. We will try to illustrate the basic features of this idea in the first decades after the war, in order to verify its changes and possible evolution in the period that we will address more closely, the 1970s. ${ }^{5}$ This will allow us both to participate in the debate about the distinctiveness of the Christian Democratic political culture, which has gained some traction among historians and political scientists in the last few years, and to give a small contribution to the ever-growing scientific discussion on European integration.

The idea of Europe of Christian Democrats in the immediate post-war had a much referenced cultural and symbolic benchmark, that of Christian Europe. ${ }^{6}$ This term

3. W. KAISER, B. LEUCHT, Informal Politics of Integration: Christian Democratic and Transatlantic Networks in the Creation of ECSC core Europe, in: Journal of European Integration History, 1(2008), pp.35-49.

4. P. CHENAUX, Les Nouvelles Equipes internationales, in: S. PISTONE (ed.), I movimenti per l'unità europea (1945-1954), Jaca Book, Milano, 1992, pp.237-52.

5. For a penetrating analysis on the post-war period, especially focused on the religious roots of European Christian Democracy's idea of Europe, see the essay of P. ACANFORA, Christian Democratic Internationalism: The Nouvelles Equipes Internationales and the Geneva Circles between European Unification and Religious Identity, 1947-1954, in: Contemporary European History, 24(2015), pp. 375-91.

6. P. PASTURE, Catholic and Christian Democratic Views on Europe Before and After World War II: Continuities and Discontinuities, in: P. KOSICKI, S. Łukasiewicz (eds), Christian Democracy across the Iron Curtain. Europe Redefined, Palgrave MacMillan, Basingstoke, 2018, pp.25-55. 
evoked the ideologically charged concept of Christendom (Christianitas), which referred to a mythical age when Europe found its unity around Christian civilization. It was most famously employed by nineteenth-century Catholic thinkers with a clear adversarial intent, against the secular ideologies, which in their view had disrupted the religious homogeneity and political stability of the continent. In the discourse of Christian Democratic politicians like Alcide De Gasperi, Robert Schuman and Konrad Adenauer - who shared Catholic faith and comparable experiences of problematic relationships with their birth nations -, the reference to Christian Europe was deprived of its intolerant and anti-modern features, being linked instead to modern values like democracy, pluralism and respect of human rights, that had only lately entered the Catholic discourse, and not without ambiguity. ${ }^{7}$

Historian Rosario Forlenza has recently argued that the notion of Christian Europe, so strong in the discourse of the first generation of post-war Christian democratic leaders, was especially indebted to the concept of Abendland (Christian West), a term that had been used by German Catholics in the nineteenth and twentieth century to express the reaction against the "twin ideas of sovereignty: sovereignty of the individual over his/her conscience and sovereignty of the nation state". Abendland was preferred to Europe, since the latter had also been used by Protestants, nationalists and other modern ideologies, responsible for the disappearing of Christianity's golden age. ${ }^{8}$ Although the occurrences of the word in the writings and speeches of European Christian Democrats are relatively scarce - the references to Christian Europe are far more frequent -, it is true that the symbolism of the Abendland proved to be extremely useful in the time of the Cold War. The oversimplified language of Cold War, indeed, relied on binary oppositions, evoking a clash of civilizations: from this point of view, the dichotomy Christianity vs. atheism, or the confrontation between the spiritual foundation of the West and the materialistic ideology of Soviet Russia, were powerful symbolic tools that were often used by the Western coalition. At the same time, Anticommunism was a fertile cultural common ground between Christian Democracy and the secular culture embodied by the United States (still often criticized for its all too material features), and furthermore allowed Catholics and Protestants to find a shared cultural and mental space. ${ }^{9}$

If we look at the documents issued by NEI, these elements emerge quite clearly and frequently. In the resolutions of The Hague Congress (17-19 September 1948), is stated that

7. P. CHENAUX, De la Chrétienté à l'Europe: les catholiques et l'idée européenne au XXe siècle, CLD, Tours, 2007. On the ambiguities see P. PASTURE, op.cit., pp.34-39. The author also highlights the connections between the idea of Christian Europe and other ideologies or political movements.

8. R. FORLENZA, The Politics of the Abendland: Christian Democracy and the Idea of Europe after the Second World War, in: Contemporary European History, 2(2017), pp.261-286, here: p.291.

9. R. FORLENZA, op.cit., p.282; D. KIRBY, The Cold War, the hegemony of the United States and the golden age of Christian democracy, in: Cambridge History of Christianity, vol.VI (edited by H. McLEOD): World Christianities, c.1914-c.2000, Cambridge University Press, Cambridge, 2006, pp. 285-303. 
"in former days the unity of Europe was based on Christianity. With the rise of individualism Europe's soul became dispersed, and materialism gradually took the place of its Christian foundations. [...] Thus European unity will not be achieved without the restoration of the Christian spirit. [...] Christianity alone can fully realize true democracy, respectful of freedom and justice in the equality and solidarity of all men of good will".

The new Europe should be built on "the subordination of economics to human interests", as we read in the final documents of Sorrento Congress (12-14 April 1950), keeping the human person at the centre of every political decision. ${ }^{10}$

Europe's role on the international scene was first and foremost to act as bulwark against Communism: NEI dedicated to this subject the 1957 Arezzo Congress, where the enfant du pays Amintore Fanfani delivered a long speech on the radical opposition between the Christian Democratic and the Communist Weltanschauung. History, according to the Italian statesman, was proving the validity of the Christian conception of society, and the fallacy of the Communist doctrine; all the interventions at the Congress - among which, the former Belgian Prime Minister Paul van Zeeland and the future Christlich Demokratische Union Deutschlands (CDU) General Secretary Konrad Kraske - insisted on the crisis of Communism after the events of 1956, and converged in presenting Europe as a pillar of the Western community. As Italian former Prime Minister Giuseppe Pella put it in the debate, "il ne peut exister un européanisme conçu comme troisième force entre l'Est et l'Ouest". ${ }^{11}$

As it is well known, the idea of Europe as a neutral third force was shared by various circles in the early years of the Cold War, from the Federalists to the Socialists, and it also gained some consensus among those Christian Democrats who lived uncomfortably the alliance with the United States. This unrealistic project was quickly abandoned and was never shared by the majority of CD parties, which strongly committed to the Western alliance since the end of the 1940s. The concept of a more autonomous and proactive European role within the international system, though, remained as a cultural subtext of their discourse. Indeed, Christian Democracy's culture of foreign policy hinged on a universalist approach, meaning that the engagement in international relations was oriented by principles that had universal validity, since they were related to the Christian concept of universal common good. International cooperation, respect for the individual, subsidiarity, social justice: they were all key values in the path to the improvement of the relations among peoples. The European Community could become an ideal setting for their fulfilment, as well as a model for

10. The English translations of these documents have been provided by W. LIPGENS, W. LOTH (eds), Documents of the History of European Integration, vol.IV, Transnational Organizations of Political Parties and Pressure Groups in the Struggle for the European Union, 1945-1950, De Gruyter, Berlin, 1991, pp.484-539, here: pp.501 and 538. A selection of NEI's documents has been published in M. GEHLER, W. KAISER (eds), Transnationale Parteienkooperation der europäischen Christdemokraten. Dokumente 1945-1965, K.G. Saur Verlag, Munich, 2004.

11. I consulted the proceedings of the Congress in AdS [Archive August de Schrijver, Kadoc, Leuven], box 7.2.4.11. Excerpts of some interventions at the Congress are in M. GEHLER, W. KAISER (eds), op.cit., pp.487-496. 
other areas of the world, as it was the place were those values were born, stemmed from Christian doctrine. ${ }^{12}$

While in the first decade of the Cold War these goals were patently obstructed by the adversarial structure of the international system, revolved around the conflict between the US and the USSR, the beginning of the new decade seemed to open up new possibilities for building a more cooperative and fair international community. Indeed, the new trends that seemed consolidating at global level - first steps of the détente, the emergence of protagonists other than the two superpowers, self-determination of peoples, in particular in the South of the world - were considered potentially concordant with the Christian Democratic worldview, since they all underlined a consistent tendency toward a greater interdependence, and therefore toward the unity of the human family. In 1965, when NEI were replaced by a stronger network (all the national CD parties were full members) called the European Union of Christian Democrats (EUCD), the newly-elected President Mariano Rumor presented an articulated view of the trends in place in international relations, in which a politically united Europe could perform a mediating function both in the West/East axis, paving the way for the reconciliation between the Western and the Eastern part of the continent, and on the North/South line, helping Third World nations in their struggle for independence and autonomy. ${ }^{13}$

This cultural architecture allowed for a further updating of the references to Christian Europe, which as well as incorporating modern values, could encompass the traditional role of model for the world, now revived by the original features of the integration process, with the mission of spreading out the tenets of Christian civilization. In an article published by the new EUCD's magazine "Panorama Démocrate Chrétien" (PDC) in 1968, Dutchman intellectual Karl Josef Hahn, president of the Christian Democratic International Centre for Information and Documentation (CDICID), summed up the features of such an approach. Europe should embrace its cultural and spiritual foundations, deeply entrenched in the Christian tradition, in order

12. I developed a more articulated argument about the universalist features of the Christian Democratic culture of foreign policy, by linking it to the elaboration of the Catholic culture, in J. CELLINI, Universalism and Liberation. Italian Catholic Culture and the Idea of International Community, 1963-1978, Leuven University Press, Leuven, 2017, pp.92-159.

13. Rumor's speech is in AdS, box 7.3.2.1. A wide selection of EUCD's documents can now be consulted in M. GEHLER, M. GONSCHOR, H. MEYER, H. SCHÖNNER (eds), Transnationale Parteienkooperation der europäischen Christdemokraten und Konservativen. Dokumente 1965-1979, De Gruyter, Berlin, 2017. This work, as well as presenting a much needed sources edition, includes an up-to-date bibliography and an essay about the history of the EUCD, written by the editors, which fills a longstanding gap in the literature. 
to become a true supranational entity with the task of promoting peace, justice and solidarity within the community of nations. ${ }^{14}$

In the next section we will see whether these cultural premises supported the most important ideological document issued by the European Christian Democracy (European Manifesto, 1976), and the first political programme of the European's People Party.

\section{Defining a political culture: the European Manifesto and EPP's Political Programme}

On 29 April 1969, EUCD's Political Bureau created the workgroup "Les orientations de la Démocratie Chrétienne dans leur confrontation avec la société moderne", in order to discuss and possibly upgrade the Christian Democratic political culture to face the challenges of modern times. Without any doubt, the world was in tumult. In particular, Western societies were shaken by a cultural revolution that challenged traditional authorities and ways of thought, including most prominently religion. At the same time, the Christian world was living a season of crisis, which was witnessed by the drop in the traditional indicators of religiosity, but also of extraordinary effervescence, finding new ways to adapt to secular societies. ${ }^{15}$ A Christian-inspired political organisation was therefore bound to reflect on the premises of its inspiration, and on their appeal for the electorate, although ideology had never been the strong suit of $\mathrm{CD}$ parties.

The workgroup held five meetings between 1969 and 1970, focusing on subjects like "Person and the human community", "The political regime and the structure of the State", "Democracy and institutions". No member was a first-rank politician, and the meetings were mostly animated by intellectuals like the Italian scholar Roberto Papini, the already mentioned Karl Josef Hahn and the Dutch theologian Gerrit Cor-

14. "En Europe" - Karl Josef Hahn wrote - "ont été développés non seulement la symphonie, le sonnet et le portrait dans la notion de l'individu selon la doctrine chrétienne, mais aussi la notion de la communauté et de la solidarité de tous les hommes pour tous les hommes. L'Europe est l'Europe seulement dans la mesure où elle se sent liée à cet universalisme, où elle agit à partir de cet universalisme pour la paix, pour un ordre juste de la communauté des peuples et pour l'aide à tous les hommes et à tous les peuples. [...] De cette manière l'Europe peut être un exemple; elle peut stimuler et aider". K.J. HAHN, Quelle Europe voulons-nous?, in: PDC, 4(1968). See also, on the same notes, the interventions of Mariano Rumor and former Belgian Prime Minister Théodore Lefèvre at EUCD's Venice Congress in 1968: CEPESS [Archive Centrum voor Politieke, Economische en Sociale Studies van de CVP, Kadoc, Leuven], box 3.2.2.

15. For a contextualization of the religious crisis and the reaction strategies of the Christian world see at least H. McLEOD, The religious crisis of the 1960s, Oxford University Press, Oxford, 2007, and Y. TRANVOUEZ (dir.), La décomposition des chrétientés occidentales 1950-2010, Centre de Recherche Bretonne et Celtique UEB, Brest, 2013. The concept of "cultural revolution" is taken from A. MARWICK, The Sixties: Cultural Revolution in Britain, France, Italy and the United States, c.1958-c.1974, Oxford University Press, Oxford, 1998. 
nelis van Niftrik. Other participants were Austrian publicist Ludwig Reichhold, Belgian young politician Gaston Geens, Italian law professor Pierluigi Zampetti and French representative Pierre Bordry. The group elaborated a Final report, which was approved by the Political Bureau in November 1970. The participants agreed on some general principles, on which the Christian Democratic doctrine should be based: personalism, subsidiarity and solidarity should sustain the democratic and pluralist architecture of State and society. The parties, moreover, should be fully "deconfessionalized", consistently with the evolution underway in the Christian Churches, as we read in a document of the workgroup

“face à l'attitude nouvelle des Églises et aux révolutions actuelles dans le monde de la culture, il est de plus en plus difficile de donner une signification proprement politique à l'inspiration chrétienne de nos partis, et ce sont plutôt les adhérents qui devraient être animés par cette 'dimension'". ${ }^{16}$

These general statements, though, did not specifically target the idea of Europe of Christian Democracy, nor were they used as basis for a political document. EUCD's Political Bureau of 3-4 May 1971, decided to move things along by renaming the study group "La pensée et l'action", charging it with the task of elaborating a text on the "Idées fondamentales" of Christian Democracy. This time as well, though, the group was not composed by influential Christian Democratic representatives, albeit more intellectuals, like French philosopher Étienne Borne, Belgian professor of political science Jean Buchmann and German political analyst Horst Teltschik, were included. The Christian Democratic group at the European Parliament, the Women section and the Youth organisation of the EUCD were also represented, respectively by Arnaldo Ferragni, Charlotte Fera and Alfredo De Poi. In the first encounter, the participants agreed on five areas, which should have been the subject of ensuing meetings: the contradictions of present times (reflection over the trends in place in the contemporary society); the role of the worker in industrial relations; the territorial redistribution of power; the person and the democratic process; the role of Europe in the world. In September 1972, after the conclusion of this first phase, dedicated to exchange of opinions and debates, the group was asked to prepare a draft for a declaration, to be presented to public opinion. In the following months, the document took the form of a manifesto, which should display the basic principles of the Christian Democratic political culture. ${ }^{17}$ A smaller group, composed by young academics Roberto Papini, Meinhard Ade (CDU) and Peter Diem (ÖVP), and by Belgian politician Dieudonné André (former press secretary of Theo Lefèvre's governments in the early 1960s), prepared a structured draft at the end of 1973, which was submitted to national parties for comments. Amendment proposals continued to arrive for the following two years (although not from every party, and with much more dilated time

16. The papers of the commission can be consulted in ACDP [Archiv für Christlich-Demokratische Politik, Kas, Sankt Augustin], 09-004-051/1-5. The quotation is taken from a paper on the "actual meaning of Christian inspiration of Christian democratic parties", prepared by Roberto Papini for the fifth meeting of the group, which is also published in: $P D C, 19(1971)$.

17. The reader can consult a draft of the Manifesto, issued in November 1972, in: M. GEHLER, M. GONSCHOR, H. MEYER, H. SCHÖNNER (eds), op.cit., document 99. 
for discussion, at least according to the papers that are available in the archives), until the Manifest of European Christian Democracy was finally approved in Paris on 21 February $1976 .^{18}$

The general principles listed in the European Manifest were not different from the ones presented in the final document of the study group "Les orientations": Christian Democrats worked for a personalist, communitarian society, rooted in Christian values and founded on the dignity of the human being. The part on Europe and its engagement in the international community, instead, was more developed. European Christian Democracy restated its commitment for the political integration of the continent, with the goal of setting up a European government with independent powers and a parliament resulting from general and direct elections. When describing the features of Europe's engagement in the international community, though, the Manifest did not rely on explicit references to the role of the continent as an example, rooted in Christian tradition. Europe's function as a model was related to classical elements of liberal and democratic culture, like the commitment to human rights protection, the preference for pluralist democracy and the implementation of the powers of international organisations. These values were fully embraced, consistently with the process started after World War II, which had led to their incorporation in the Christian Democratic political culture. Nonetheless, we can detect some lexical markers that denote a not yet abandoned link with a religious worldview. In particular, the view of the international order hinged on the establishment of "social justice at world level", "at the service of the universal common good". We have already mentioned the concept of "universal common good", which was deeply embedded in the Catholic discourse; but what caused a raging debate within the Christian world, especially in the late 1960s and the 1970s, was the issue of international social justice. The discussion over the inequalities between rich and poor countries, the efforts to remove them, and the link with universal peace, involved the Church's Magisterium - most famously in Paul VI's ground-breaking encyclical Populorum progressio (1967) -, ecclesial communities and lay organisations, theologians and intellectuals, sometimes with a high degree of radicalism. ${ }^{19}$ Christian Democrats maintained a moderate view, far from endorsing a revolutionary attitude toward the existing power system, but they did acknowledge the centrality of the North/South divide in the contemporary world. Europe, in their view, should commit to rebalancing the gap between industrialized and underdeveloped countries through cooperation and soli-

18. I have reconstructed the building process of the Manifest by consulting the papers held in: ACDP, 09-004-021; CVP/PSC [Archive Christelijke Volkspartij/Parti Social Chrétien, Kadoc, Leuven], box $10.3 / 1$.

19. J. CELLINI, op.cit., pp.71-85. The most radical approach to the issue of international social justice was employed by Liberation theology, which was born in Latin American mostly within the Catholic milieu (but also with important Protestant contributions), and exerted a remarkable influence on Western European progressive Catholicism: see G.-R. HORN, The Spirit of Vatican II. Western European Progressive Catholicism in the Long Sixties, Oxford University Press, Oxford, 2015. 
darity, "making sure not to impose to other countries [its] scheme of civilization and development". ${ }^{20}$

This approach to international relations was not a prerogative of European Christian Democracy, but instead was shared by Christian Democrats at world level, as we may infer from the Political Manifest of the World Union of Christian Democrats (WUCD), approved in Rome on 16 July 1976, and prepared by a World Ideological Commission. The homogeneity between the two manifestos should not surprise us, since many members of the group "La pensée et l'action" - like Hahn and Papini, Swiss historian Urs Altermatt and Italian politicians Luigi Michele Galli and Pier Luigi Zampetti - were also involved in the world ideological commission. The other participants were mostly Latin American, like Venezuela Foreign Minister Aristide Calvani, Uruguayan MP Juan Pablo Terra or Chilean Claudio Orrego Vicuña, a close collaborator of former President of Chile Eduardo Frei. ${ }^{21}$ In the document we can observe an enhanced attention for the "state of dependence of the peoples of the Third World" due to the "concentration of political-military power and of the present concept of the 'stability' of the international system", but the theoretical framework was clearly oriented by the "Christian concepts of universalism and solidarity", which linked the pursuit of lasting peace with the values of "freedom, international social justice, self-determination and the full respect of human rights".

Here we must at least mention one problematic issue in the discourse of European Christian Democracy. While the acknowledgment and support to the decolonization process had entered the vocabulary of CD parties - also as a way to compensate for the loss of global influence, though a privileged relationship with newly independent countries -, the antidemocratic regimes of Southern European countries (especially Spain and Portugal, where Christian Democracy had deeper roots than in Greece) were not condemned with the same strength, mainly for geopolitical considerations. EUCD's Spanish équipe complained about this fact when requested to express an opinion about the European Manifest, and eventually did not sign the document, while it did agree to sign WUCD's Political Manifest. ${ }^{22}$ Also difficult were the relations with opposition movements of Christian Democratic inspiration in Eastern Europe: in December 1966 EUCD formed a East/West commission (already active within the

20. The quotations are taken from the French version of the Manifest, published in PARTI POPULAIRE EUROPÉEN, Programme et Statuts avec un historique et de multiples références jusqu'au début de l'année 1984 (2nd edition), Secrétariat Général du PPE, Bruxelles, 1984, pp.23-30, my translation.

21. See the preparatory drafts, the works of the Commission and the final text of the Manifest in ACDP, 09-004-054/8, 09-004-047/5 and 09-004-043/1. The following quotations are taken from PARTI POPULAIRE EUROPÉEN, op.cit., pp.31-40, my translation. In his history of the EPP, Thomas Jansen wrote that German politician Hans August Lücker, who would be actively involved in drafting EPP's Statutes and first Political Programme, had "an active hand" in the formulation of both manifestos, but I found no proof of his regular involvement in the workgroup and the commission. T. JANSEN, The European People's Party. Origins and Development, Palgrave MacMillan, Basingstoke, 1998 , p.66.

22. ACDP, 09-004-022/2. On the complicated relationship between Spanish Christian Democracy and the EUCD, in particular after Franco's death, see M. GEHLER, M. GONSCHOR, H. MEYER, Einleitung, in: Idem. (eds), op.cit., pp.39-41. 
NEI, but later dissolved), which in 1967 prepared an ambitious document, suggesting to set up a series of initiatives aimed at educating a Christian Democratic ruling class in Central and Eastern Europe..$^{23}$ In the following years, though, these proposals were not followed up by concrete steps, and the Commission became a simple forum of discussion about East/West relations and the life beyond the Iron Curtain. All in all, EUCD remained quiet "Western-centric" through all of its existence.

EUCD's Manifesto served as ideological source for the first political document of the European People's Party (EPP's political programme), which was officially founded in Brussels on 29 April 1976. ${ }^{24}$ Talks about the creation of a European party had frequently surfaced in EUCD's meetings and in speeches and writings of Christian democratic representatives, starting from the proposal made by the Dutchman Tjerk Westerterp in 1970, but they had not been followed up by concrete measures until 1975, after the EC's heads of state and government's decision to fix the date of the first direct elections to the EP for 1978 (we will come back to this issue in the next section). On 26 September 1975, EUCD's Political Committee - a new body of the organisation, founded in 1971, composed of members of the EUCD and the CD group at the European Parliament - set up a working group to study the programme, statutes and name of a Christian Democratic European party. Wilfred Martens, President of CVP, and Hans August Lücker were listed as rapporteurs, while two members for every équipe of EC member states could join the group. Drafts of the Statutes, written by Martens and Lücker, were discussed on 17-18 November in Brussels and on 16 January 1976 in Luxembourg, before being approved by the Political Committee in Paris on 21 February. The political programme was approved, without amendments, by the first EPP Congress in Brussels, on 6-7 March 1978. ${ }^{25}$

During the meetings of the Political Commitee, and in the drafts of the political programme, the section on international politics and the role of Europe was not much debated, in part because it did not yet entail operative decisions (a common European foreign policy, also at the time, was a distant goal), but in part because it was fundamentally shared by Christian Democrats. ${ }^{26}$ Here are its basic tenets: in the new mul-

23. The initiatives included missions of Western cultural and religious personalities beyond the Iron Curtain, the organisation of meetings by Western non-political institutions, and the facilitation of internships, post-graduate studies and cultural exchanges for Central and Eastern Europeans, so that they could become familiar with Christian democratic politics and European institutions: the document is in ACDP, 09-004-041/1. On Christian Democracy in Central and Eastern Europe see now P. KOSICKI, S. ŁUKASIEWICZ (eds), op.cit.

24. The most comprehensive historical account on the EPP is T. JANSEN, S.v. HECKE, At Europe's service. The Origins and Evolution of the European People's Party, Springer, 2011, where the reader can also find the text of the first political programme (Annex I, pp.253-281). For the founding stage, see S.v. HECKE, The Fractious Foundation of the European People's Party, in: J.-D. DURAND (ed.), op.cit., vol.II, pp.173-184.

25. T. JANSEN, S.v. HECKE, op.cit., pp.38-39. I have consulted the papers of the workgroup in ACDP, 09-007-001/1. See now also the documentation made available by M. GEHLER, M. GONSCHOR, H. MEYER, H. SCHÖNNER (eds), op.cit., in particular documents number 162, 164, 171, 172, 174.

26. See the notes of group members Josef Müller, Ferdinando Martini, Franz Ludwig von Stauffenberg, Henri Bourbon, Meinhard Ade and Maurice Dewulf in ACDP, 09-007-006. 
tipolar context of the 1970s, Europe should work as an element of balance and dialogue, by offering its full support to international organisations and implementing fundamental values like the respect of human rights. The traditional reference to a special task of the Old Continent, intended as a politically integrated entity, as a facilitator of dialogue on the East/West line and a promoter of development and social justice in the North/South axis, was restated, this time with a more detailed reference to recent documents and conventions that seemed to point toward the right direction, like the Lomé Convention, the Helsinki Final Act and the Tindemans report on the future of the Community, all signed and issued in 1975.

The references to a religious Weltanschaunng, though, were further limited with the foundation of the European People's Party, consistently with the process of "deconfessionalisation" of Christian-inspired political parties, which had accelerated since the 1960s. In the political programme, for instance, we do not find a mention of the "universal common good", that was still present in the European Manifest. More symbolically still, the words "Christian Democratic" were expunged by the name of the new organisation - they were quoted in the subtitle, Federation of Christian Democratic Parties of the European Community, which was however very rarely used -, after a debate that saw the Germans and the Dutch at the opposite sides of the spectrum. The latter wanted to reaffirm the continuity with the Christian Democratic tradition, while the former preferred a more neutral name, able to generate an appeal also to other political forces, namely the Conservative parties of Great Britain and the Scandinavian countries. ${ }^{27}$

In the end, a compromise was reached by preventing the Conservatives from joining the party, but leaving the door open for a future rapprochement, which meant diluting and possibly overcoming the connection to Christian identity. This is a process that must be kept in mind as we move on to the last part of our argument, where we will deal with the relationship between the idea of Europe of Christian Democracy, and the actual steps taken for its implementation.

27. The debate found a resolution in the Political Committee's meeting of 20-21 February 1976, when the European Manifest was also approved. The board voted between three possible choices for the name of the new party: "Parti Populaire Européen" (proposed by German Heinrich Böx); "Parti Populaire Européen des Démocrates Chrétiens" (proposed by Roelof Kruisinga for the Netherlands); "Parti Populaire européen (Union ou Féderation des Partis Démocrates Chrétiens)" (proposed by French Jean-Marie Daillet and Luxembourger Jacques Santer), and the latter was approved. The minutes of the meeting (ACDP, 09-007-001/1), have been published by M. GEHLER, M. GONSCHOR, H. MEYER, H. Schönner (eds), op.cit., document 173. About the theoretical and practical relationship between Christian Democracy and Conservative parties, there is already a large amount of literature: see for introduction P. DELWIT (ed), Démocraties chrétiennes et conservatismes en Europe. Une nouvelle convergence?, Éds de l'Université de Bruxelles, Bruxelles, 2003. 


\section{From theory to practice}

In the discourse of Christian Democracy about the idea of Europe one premise was constantly restated: Europe had to become an integrated political community in order to play an effective role in the international system, which meant speaking with a sole voice and implementing a common foreign policy. European integration, or European unity, was an architrave of the public rhetoric of Christian Democrats: how this aspiration was translated into actual politics, though, is a complex issue, which does not have a straightforward answer. At the same time, it can not be avoided by the historian of ideas. Theory and practice, cultural elaboration and policy implementation, cannot be considered different dominions, as per realist or structuralist theories that juxtapose the plane of political decisions, driven by economic and political interests, and the plane of the public discourse, often seen as the dimension of apparent beliefs, which rationalise strategies chosen for other reasons. ${ }^{28}$ The literature on European integration has famously revised the idealist interpretations, that animated the first accounts of the process of Europe-building, in favour of more historicallygrounded approaches, which have underlined first the importance of structural imperatives, and later the centrality of a wide array of actors, as well as the NationStates, in shaping the European Community. ${ }^{29}$ Ideas and cultures now can be brought back to the mix, not as primary causes but as factors, which influence the positions and the decision-making process of institutional and non-institutional actors. In our case, we will not enter the complex theoretical debates over how much ideas can impact policies, but we will propose a historical interpretation of the degree of correspondence between Christian Democracy's idea of Europe and the actions undertaken for its fulfilment.

We have already mentioned NEI's contribution to the early stages of European integration. EUCD's role, instead, was much less active, as argued by sympathetic literature as well. ${ }^{30}$ It is true that the external conditions were also changed: Christian Democracy in the 1960s and the 1970s was no more the dominant political force in Western Europe, as it had been in the 1950s. German Christian Democrats lost power

28. The historiography has long acknowledged the need for more nuanced interpretations: see for a methodological introduction C. PARSONS, Showing Ideas as Causes: The Origins of the European Union, in: International Organization, 1(2002), pp.47-84, and D. BÉLAND, Ideas, Institutions, and Policy Change, in: Journal of European Public Policy, 5(2009), pp.701-718.

29. See a reflection over the state of the art of the literature in W. KAISER, A. VARSORI (eds), European Union History. Themes and Debates, Palgrave MacMillan, Basingstoke, 2010. For a theoretical introduction to the main theories of European integration see S. SAURUGGER, Theoretical Approaches to European Integration, Palgrave MacMillan, Basingstoke, 2014 (or. Éds ScienesPo, Paris, 2009).

30. R. PAPINI, The Christian Democrat International, Rowman \& Littlefield, Lanham, MD, 1997, pp. 86-87 (or. FrancoAngeli, Milano, 1986); T. JANSEN, S.v. HECKE, op.cit., p.28. For a long-term balanced view see W. KAISER, Europeanization of Christian Democracy? Negotiating Organization, Enlargement, Policy and Allegiance in the European People's Party, in: W. KAISER, H. MEYER (eds), Societal Actors in European Integration: Polity-Building and Policy-Making 1958-1992, Palgrave MacMillan, Basingstoke, 2013, pp.15-37. 
for the first time in 1969, followed in 1970 by their Austrian colleagues. In Italy, Belgium and the Netherlands CD parties were haemorrhaging votes, while in France there was no distinctly Christian Democratic party after the dissolution of the MRP in 1965. Consequently, their weight in European institutions was also decreasing, mostly in favour of Socialist parties (in 1975 the Christian Democratic group lost its relative majority for the first time in the history of the European Parliament). Nonetheless, there was one major achievement that could be accomplished by Christian Democrats, in order to implement the idea of Europe that was expressed by their political culture: political integration needed a stronger cooperation among likeminded political parties, that was not provided by a rather powerless network like the EUCD. Moreover, the creation of a single party would have ended the possible conflicts of competence between the EUCD and the CD group in the European Parliament. ${ }^{31}$ Although the effectiveness of party cooperation is not necessarily gauged by the formal organisation of European-level party organisations, the accomplishment of this task can be a good measure to evaluate the relation between ideas and their implementation. ${ }^{32}$

The possibility to found a European party became to circulate among Christian Democrats since the beginning of the 1970s, in parallel with the deepening of their cultural elaboration within the workgroups of the EUCD. In the study days organised by EUCD's Dutch équipe in June 1970, Tjerk Westerterp (who was member of the workgroup "Les orientations") made a proposal in this regard, which was relaunched by the Italian MP Giuseppe Bartolomei in May 1971, and also acknowledged, albeit with caution about its immediate implementation, by EUCD's President Mariano Rumor in the same month. ${ }^{33}$ Belgian Minister of State Robert Houben insisted on the issue with an articulated study in 1972, establishing an explicit link between the formation of a European party, the strengthening of the Christian Democratic identity and the benefits for European integration. ${ }^{34}$ In the following years, though, the subject

31. A project on the history of the CD group is currently underway at the Historical Archives of the European Union, in Florence; at this time, see H. MEYER, Die christlich-demokratische Fraktion des Europaïschen Parlaments im Spannungsfeld verschiedener transnationaler Kooperationsformen 1965-1979, in: Journal of European Integration History, 1(2011), pp.31-45. This representative body has not been at the centre of our analysis, because it was constitutively less interested in the elaboration of a political culture.

32. Party cooperation should be understood "as a complex multi-level governance system developed and run by a fragmented societal actor. This governance system involves a large set of party actors at the national, transnational and EC levels including party-affiliated political foundations": W. KAISER, Europeanization of Christian Democracy..., op.cit., p.15.

33. Westerterp's report and Bartolomei's intervention are in ACDP, 09-007-001/1, from which I have gathered all the data used for this section, unless otherwise stated. Westerterp's contribution can now be consulted in M. GEHLER, M. GONSCHOR, H. MEYER, H. SCHÖNNER (eds), op.cit., pp.370-375. Rumor's speech (to the study days organised by the CD group in the European Parliament, 5-7 May 1971) is in ASS [Archivio Storico del Senato, fondo Mariano Rumor, Roma], box 126, folder 130.

34. Houben expressed a familiar idea of Europe, as a model of civilization for the world, thanks to its cultural tradition and peculiar institutional architecture: R. HOUBEN, La formation d'un Parti Démocrate Chrétien européen, in: PDC, 4(1972). 
was not picked up, so much so that future President of the European Commission Jacques Santer still complained about the delay in a meeting of May 1975, deploring "EUCD's feeble representativity" and its lack of impact in European politics. Things were set in motion only in September 1975, in view of the upcoming first direct elections of the European Parliament.

One of the reasons for this delay, arguably the main reason, was that while Christian Democrats wanted to change their organisational structure in order to accelerate the process of European integration, the political landscape of the European Community was also changing. The accession of United Kingdom, Denmark and Ireland in 1973 led to the entry of conservative parties, which did not join the Christian Democratic group. The issue of the relation with the Conservatives soon became the focal point in the discussions about a tighter party cooperation at European level, and it also dominated the preparatory phases of the EPP's foundation. The Germans presented several documents in favour of an institutionalised collaboration between the two political families, including a projection of the results in the upcoming elections, which aimed at underlining the CDU's centrality in deciding future alliances (CDU vetoed the hypothesis of a coalition with the Socialists). The resistance coming from other national parties, headed by the Dutch and the Italians, was overcome with a compromise: on the one side, the EPP did not accept conservative parties as founding members, although its name did not make reference to the Christian Democratic identity ${ }^{35}$ On the other side, the Germans were free to set up the "European Democratic Union" (1978), an association of "Christian Democrat, conservative and noncollectivist parties", which included the British Tories and with French Neo-Gaullists led by Jacques Chirac. ${ }^{36}$

If the relationship with conservative parties was an important factor, which delayed the formation and changed the nature of the European Christian Democratic party, causing a gap between ideas and their translation into practice, another consideration can help us to shed light on this topic from a historical perspective. The problem we need to deal with is a central one in the second half of the twentieth century, as it concerns the relation between Nation-States and Europe, namely between national and European identity. ${ }^{37}$ Research has shown how social groups are unlikely to give up their nation-state identity altogether in favour of a collective

35. On this matter, see the interesting letter of prominent CDU politician Kai-Uwe von Hassel to party's chairman Helmut Kohl (16.03.1976), where the argument and the disagreements between the Germans and the Italians are clearly laid out: M. GEHLER, M. GONSCHOR, H. MEYER, H. SCHÖNNER (eds), op.cit., document 179.

36. This initiative initially caused some frictions within the EPP. In the following decades the party opened up to conservative and other like-minded parties, although the issue - like in the case of the Italian Forza Italia - continued to generate harsh debates: S.v. HECKE, Démocrates chrétiens et conservateurs au Parlament européen: mariage d'amour ou de raison?, in: P. DELWIT (ed), op.cit., pp.323-343.

37. The subject has been addressed mostly by sociologists and political scientists: a recent picture is in B. WESTLE, P. SEGATTI (eds), European Identity in the Context of National Identity: Questions of Identity in Sixteen European Countries in the Wake of the Financial Crisis, Oxford University Press, Oxford, 2016. 
European identity; rather, "Europe" is incorporated and coexists with given nationstate identities, which vary in space and time. ${ }^{38}$ The same holds true for political parties, even for those with a strong pro-European discourse like Christian Democracy, especially when in power; moreover, the harmonization between national interests and European integration did not follow the same path for every member state. ${ }^{39}$ Although the literature has revised the interpretation of the 1970s as a decade of stalemate and crisis for European integration, it is clear that a comprehensive historical account must focus on the shifting balance between the national and the supranational dimension, avoiding both the extremes of the analytical spectrum, i.e. teleological theses that consider the European union as the inevitable outcome of the integration process, and reconstructions focused on the predominance of national interests. ${ }^{40} \mathrm{~A}$ more detailed analysis, which is not the scope of the present work, should also consider the possible conflict within parties, between pro-European advocates, who were normally active in European institutions and transnational party networks, and more moderate members, who were mostly engaged in national politics.

For what concerns the subject of our study, this cleavage seems to exist. From the study of archival sources, one gets the impression that national CD parties did not follow closely the work of the international organisation, which was generally intended as a forum of discussion and exchange of ideas, but with little practical impact. It can be argued that Christian Democracy continued to play a significant role in European integration in the 1960s and the 1970s (and also later), not primarily as political parties, but as networked party politicians, who were able to take advantage of the complex intersection between national and supranational, formal and informal politics that shaped the European Community ${ }^{41}$ Some of the most forward-thinking documents about the future of the Community, like the Bertrand report (14 October 1974) and the famous Tindemans report (29 December 1975), were signed by Christian Democrats. At the same time, the caution in authorizing the deferment of government powers to the European level - especially in the fields of security and foreign policy -, and the strategic divergences existing between national parties, exerted a

38. T. RISSE, A European Identity? Europeanization and the Evolution of Nation-State Identities, in: M. GREEN COWLES, J. CAPORASO, T. RISSE (eds), Transforming Europe. Europeanization and Domestic Change, Cornell University Press, Ithaca, NY, p.202.

39. The literature has recently begun to deal with this pivotal problem, also from a historical perspective: see L. BONFRESCHI, G. ORSINA, A. VARSORI (eds), European Parties and the European Integration Process, 1954-1992, Peter Lang, Brussels, 2015, and G. THIEMEYER, J. RAFLIK (eds), European political parties and the first direct elections to the European Parliament, Nomos, BadenBaden, 2015.

40. See the account of A. VARSORI, The European Construction in the 1970s. The Great Divide, in: A. VARSORI, G. MIGANI (eds), Europe in the International Arena during the 1970s. Entering a Different World, Peter Lang, Brussels, 2011, pp.27-39.

41. W. KAISER, Christian Democracy..., op.cit., p.325. One case study about the 1990s is K.M. JOHANSSON, Europarty Influence and Its Limits: The Case of the European People's Party and the Amsterdam Treaty, in: Journal of European Integration History, 1(2016), pp.79-94. 
counterforce that restrained the full realization of the idea of Europe expressed by the Christian Democratic political culture.

\section{Conclusions}

In December 1973, the heads of state or government of the nine members of the European Community issued the Declaration on European Identity, which was initially thought as a transatlantic declaration aimed at ameliorating the strained relations between Europe and the US, but later became a European Chart of values. ${ }^{42}$ The signatories agreed on the determination "to build a society which measures up to the needs of the individual", based on the principles of representative democracy, rule of law, social justice and respect for human rights. In the international arena, according to the Declaration, Europe should work as an element of balance, with the goal of establishing friendly and just relations with every actor of the international community - neither Communism nor the Cold War were mentioned -, and especially with the South of the World.

Christian Democrats could identify with this declaration of principles: most elements were concordant with their view, which we have addressed in particular through the analysis of the European manifesto and of the EPP's political programme. We have seen how 1970s Christian Democracy's idea of Europe had changed some features since the first post-war decades, when it was more explicitly linked to Cold War schemas and to a model of Christian civilization. The references to the Christian Weltanschauung, in particular, would further thin out in the 1980s and beyond, as the EPP became a federation of centre-right parties, not specifically defined by a religious inspiration. Now we can close this analysis by adding two considerations, which will contribute to the debate about Christian Democracy and European integration.

The first one concerns the distinctiveness of the Christian Democratic political culture. ${ }^{43}$ In my opinion, the idea of Europe emerging from the discourse of Christian Democracy is recognisable and distinct, especially for what concerns its connections to a religious worldview, which are still ascertainable in the early stages of the EPP's history. One peculiarity of this idea was that it could be used as a sort of bridge toward other political cultures, which shared the same universalist features - we can think about the convergences on the issue of human rights with the Liberal culture, or on social justice with the Socialist one. This trait was bound to make the Christian Democratic political culture less ideologically structured than others, but also more flexible and expendable in political negotiations. This is why we can find some basic

42. I. MEGENS, The December 1973 Declaration on European Identity, in: J. VAN DER HARST (ed), Beyond the Customs Union: The European Community's Quest for Deepening, Widening and Completion, 1967-1975, Peter Lang, Brussels, 2007, pp.317-340.

43. Scholars have long dismissed this issue, which is only recently finding a scientific assessment: see the considerations of P. ACANFORA, op.cit., pp.377-378. 
ideas of the European manifest, or of the EPP's political programme, in European charter of values like the 1973 Declaration or the Treaty on European Union (1992). At the same time, moving on to the second consideration, it is well known that these political documents remained mostly on paper, or were very slowly implemented. This was mirrored by a comparable gap between the idea of Europe of Christian Democracy and the steps taken for its translation into practice. As often is the case, cultural elaboration and political action moved at different speed, because of the role played by external factors and diverging interests at national and party level. Historians need to take into consideration both of them, and the interaction between them, in order to offer a balanced picture of this recent and topical phase of European history. 